\title{
First trimester enterovirus IgM and beta cell autoantibodies in mothers to children affected by type 1 diabetes autoimmunity before 7 years of age.
}

\author{
Alexander Lind ${ }^{1}$, Kristian F. Lynch², Markus Lundgren', Åke Lernmark ${ }^{1}$, Peter \\ Almgren ${ }^{1}$, Anita Ramelius ${ }^{1}$, Leena Puustinen ${ }^{3}$, Heikki Hyöty ${ }^{3,4}$, and Annika Lundstig ${ }^{1}$
}

1) Department of Clinical Sciences, Lund University Clinical Research Center, Skåne University Hospital, 20502 Malmö, Sweden

2) Health informatics Institute, Morsani College of Medicine, University of South Florida, Tampa FL, U.S.A

3) Faculty of Medicine and Life Sciences, University of Tampere, Biokatu 10, 33520 Tamprere, Finland

4) Fimlab Laboratories, Pirkanmaa Hospital District, Tampere, Finland

Corresponding author:

Annika Lundstig, Ph.D.

Lund University Diabetes Centre

Department of Clinical Sciences

Malmö University Hospital, CRC

Jan Waldenströms gata 35

20502 Malmö, Sweden

E-mail: annika.lundstig@med.lu.se

Phone:+46 709-532199, 46 40-391019 


\begin{abstract}
Background Autoimmune (type 1) diabetes (T1D) is a frequent chronic disease in children and adolescents globally. Gestational enterovirus (EV) infections have been associated with an increased risk for T1D in the offspring. We test the hypothesis that EV infections during the first trimester were associated with beta cell autoantibodies in mothers of children who developed islet autoantibodies before 7 years of age.
\end{abstract}

Materials and Methods Local registries were used to identify mothers to children born 20002007 who developed either beta cell autoantibodies or T1D during follow up. Serum samples from the first trimester were located in the Biobank. A total of 448 index mothers were identified and compared to 891 matched control mothers. EV-IgM was determined in a capture enzyme immunoassay. Beta cell autoantibodies were analyzed in standard radio binding assays.

Results The frequency of EV-IgM in index mothers was 20\% (89/448), which did not differ from the control mothers $(20 \% ; 175 / 891)(p=0.922)$. Index mothers had multiple beta cell autoantibodies more often than control mothers $(\mathrm{p}=0.037)$.

Beta cell autoantibodies were increased during the November - April winter months in index compared to control mothers $(\mathrm{p}=0.022)$. The observed difference was possibly explained by the months of February-April ( $\mathrm{p}=0.014)$. Concomitant EV-IgM and beta cell autoantibodies tended to be more common among index compared to control mothers $(\mathrm{p}=0.039)$.

Conclusion The present study reveals a possible interaction between EV-IgM and beta cell autoantibodies during the first trimester in mothers to children who developed either beta cell autoantibodies or T1D before 7 years of age.

Funding Barndiabetesfonden, Stiftelsen Olle Engkvist Byggmästare, Sydvästra Skånes Diabetesförening, Lisa och Johan Grönbergs Stiftelse, Lunds Revisorer and HKH Kronprinsessan Lovisas förening för barnasjukvård. 


\section{Introduction}

Type 1 diabetes (T1D) is the result of autoimmune destruction of pancreatic beta cells. The disease is one of the most frequent chronic diseases in children and adolescents globally. The etiology of the disease has not been clarified but viruses have been considered an environmental factor that may induce a first beta cell autoantibody directed against either insulin (IAA), GAD65 (GADA), or both(Cabrera-Rode et al., 2003; Sarmiento, Cubas-Duenas, \& CabreraRode, 2013). Following the appearance of a first autoantibody, multiple autoantibodies may appear as strong biomarkers of an immune pathogenic process leading to clinical onset of diabetes(Baekkeskov et al., 1987; Barker et al., 2004). (Eisenbarth, 2004) The appearance of a first beta cell autoantibody in the child may follow an EV infection(Sadeharju et al., 2001; Salminen et al., 2003). However, it has also been reported that EV infection may accelerate the pathogenesis resulting in a more rapid progress to clinical onset of diabetes(Beyerlein, Wehweck, Ziegler, \& Pflueger, 2013; Hober \& Sane, 2010; Hober \& Sauter, 2010). Whether gestational EV infections also can be associated with an increased risk for beta cell autoimmunity and type 1 diabetes in the offspring is controversial(Dahlquist, Ivarsson, Lindberg, \& Forsgren, 1995; Lindehammer, Hansson, et al., 2011; Tauriainen et al., 2007). However, mothers with HLA-DQ 2/2 or 2/X genotypes showed an increased risk for beta cell autoantibodies at delivery. After adjusting for parity, maternal age, year of birth, and season of early pregnancy, early pregnancy EV-IgM combined with DQ2/2 or 2/X increased the risk for beta cell autoantibodies(Resic Lindehammer et al., 2012). It is unclear if the risk for T1D in the offspring differs if the mother already had beta cell autoantibodies in early pregnancy or acquired them during pregnancy(Lernmark, Lynch, \& Lernmark, 2006; Lindehammer, Hansson, et al., 2011).

Our objective was to analyze EV-IgM along with GADA, IA-2A, and all three variants (amino acid R, W or Q at position 325) of ZnT8A in serum samples obtained from pregnant women during their first trimester. We test the overall hypothesis that concomitant exposure to EV and beta cell autoimmunity during the first trimester increased the risk for postpartum beta cell autoantibodies, T1D, or both. 


\section{Materials and Methods}

\subsection{Study population}

The number of live births in the Skåne County between year 2000 and 2007 was 98,487, median per year: 12,277 and range between 11151 - 13837 per year (Figure 1). Between October 2000 and August 2004, 35,758 children were screened at birth in the Diabetes Prediction in Skåne (DiPiS) study(K. Larsson et al., 2004). Between September 2004 and July 2007, 24,951 children were screened for The Environmental Determinants of Diabetes in the Young (TEDDY) study (Group, 2007). Taken the two studies together, more than 5000 children were followed either annually from two years of age in DiPiS or quarterly from 3 months of age in TEDDY(Group, 2007; K. Larsson et al., 2004). In 2014, 688 children born 2000-2007 who had developed a beta cell autoantibody or T1D were identified.

The Southern Sweden Microbiological Biobank (SSM-Biobank) has been collecting serum samples during the first trimester (gestational weeks 10-16) in $>98 \%$ of all pregnant women in Skåne (Lindehammer, Hansson, et al., 2011; Ryding et al., 2008). After confirmed pregnancy at the first visit to the Maternity Care Clinic, a blood sample was taken for the analysis of Rubella, HIV, Hepatitis B and Syphilis. The leftover sera were stored at $-20^{\circ} \mathrm{C}$ for up to 20 years in the SSM-Biobank for research purposes (Lindehammer, Hansson, et al., 2011; Ryding et al., 2008). It was possible to obtain the first trimester sample from 448/688 (65\%) mothers (index mothers) giving birth to a child who during 2000-2014 had developed either a beta cell autoantibody or T1D (Figure 1). Of the 448 index mothers, 7 healthy mothers had beta cell autoantibodies, 21 had T1D and 19 were diagnosed with gestational diabetes (Table 1). There were seven samples with insufficient volumes (Figure 1).

The control mothers were matched for age ( \pm 2 years), gender of the child, birth date of the child ( \pm 2 months) and birth place (hospital). Five control mothers for each index mother were first identified in the database of the screening for DiPiS and TEDDY, respectively. The next step was to find these mothers in the registry of SSM-Biobank. Here it was possible to select two control mothers for each index mother and in the final step we located samples from 905 control mothers in the actual sample repository. Of 891 available control mothers, 17 healthy mothers had beta cell autoantibodies, 9 were diagnosed with T1D, 2 were diagnosed with type 2 diabetes and 51 were diagnosed with gestational diabetes (Table 1). Insufficient serum volume made it necessary to exclude 14 control mothers (Figure 1).

\subsection{Enterovirus IgM analysis}

IgM class enterovirus antibodies were analysed using a capture EIA method and a mixture of three enterovirus antigens (Coxsackievirus B3, Echo11 and Coxsackievirus A16) as previously described $^{19}$. Briefly, microtiter plates (FISHER 10394751 (cat 439454) Nunc-immuno tm plate 
maxisorp-levy MedixMAB ${ }^{\mathrm{TM}}$ anti-human IgM 7408 SPRN-5 (Kaupunki ei Cat.no 100084) were first coated over night with anti-human IgM monoclonal antibody (Anti-h IgM 7408 SPRN-5 Medix Biochemica, Espoo, Finland), washed four times with EIA washing buffer and blocked with $0,1 \%$ BSA in PBS. Serum samples diluted 1/100 in EIA buffer were added and incubated for 1 hour at $37^{\circ} \mathrm{C}$. The plates were washed 4 times with EIA washing buffer and heat inactivated virus antigen mixture (CVB3, ECHO11 and CAV16) was added in dilution 1/400 and incubated for 30 minutes at $37^{\circ} \mathrm{C}$. After washings, a mixture of biotinylated rabbit antibodies raised against each of the virus antigens CVB3/ECHO/CAV16 was added and incubated for 30 minutes in room temperature. The plates were then washed 6 times with EIA washing buffer. Streptavidin-horseradish peroxidase conjugate (HRP-Conjugated Streptavidin, BD Pharmingen ${ }^{\mathrm{TM}}$, BD Biosciences, San Diego, CA, USA ) diluted 1/1000 in EIA buffer was added and incubated in dark for 30 minutes in room temperature. After the final washing a color reacting substrate (orto-phenylenediamine-dihydrochloride, Sigma-Aldrich, St. Louis, USA) was added, incubated in dark for 15 minutes in room temperature, stopped with $\mathrm{H}_{2} \mathrm{SO}_{4}$ and the absorbances were read at $490 \mathrm{~nm}$.

The cut-off for being enterovirus IgM positive was the level of background control multiplied by four. In addition, a less stringent cut-off (three times the absorbance of the background) was used in sensitivity analyses. The analyzing laboratory was blinded to the identity of the samples.

\subsection{Beta cell autoantibody assay}

Coupled in vitro transcription and translation was performed using the TNT SP6 coupled reticulocyte lysate system (Promega, Southhampton, UK) ${ }^{\text {(Kjelleras, Vaziri-Sani, \& Agardh, 2011). }}$ Established standardized radioligand assays were used to determine the autoantibody levels to GADA, IA-2A and ZNT8A as previously described(Grubin et al., 1994). Briefly, serum samples, diluted $1 / 25$ in antigen buffer were incubated with ${ }^{35}$ S-methionine labeled GAD65, IA-2 or ZnT8 over night at $+4^{\circ} \mathrm{C}$ in 96 well plates. The reaction mixture was transferred to filtration plates and incubated $+4^{\circ} \mathrm{C}$ for 1 hour with $50 \mathrm{uL} 20 \%$ Protein A Sepharose (Thermo Fisher Scientific, Waltham, MA USA) suspended in antigen buffer on a plate shaker. Unbound antigen was removed by washing and the radioactivity of Protein A Sepharose antibody-bound antigen counted in a Microbeta Trilux 1450-021 (PerkinElmer, Waltham, Massachusetts, USA) (Grubin et al., 1994).

Levels of beta cell autoantibodies in the maternal first trimester serum samples were determined from the international WHO standard of GADA and IA-2A (PMID: 10398550) defining titers in units/mL (U/mL).

The cut-off was defined at the 98th percentile for GADA, 99.0th percentile for IA-2A and the 99.5th percentile for ZNT8A from the control serum samples. Our laboratory is participating in 
the Islet Autoantibody Standardization Program (IASP) (H. E. Larsson et al., 2008; Torn et al., 2008). In the last workshop our GADA radiobinding assay showed a workshop sensitivity of $54.0 \%$ and workshop specificity of $98.9 \%$. In the IA-2A assay sensitivity was $74.0 \%$ and specificity 100\%; ZnT8RA, 52.0\% and 98.9\%, respectively, ZnT8WA, $48.0 \%$ and 98.9\%, and ZnT8QA, $38.0 \%$ and $98.9 \%$, respectively.

\subsection{Statistical analysis}

Sample size and power calculation: Prior data indicate that the probability of exposure among controls is $\mathrm{P} 0=0.10$ and the correlation coefficient for exposure between matched index and control mothers is $\theta=0.25$. We will be able to detect true odds ratios for disease of 0.59 or 1.58 in exposed subjects relative to unexposed subjects with probability (power) 0.8 . The Type I error probability associated with this test of the null hypothesis that this odds ratio equals 1 is 0.05 .) SPSS $24^{\circledR}$ statistical package (SPSS Inc. IBM, Chicago, Illinois, US) was used for $\mathrm{X}^{2}$ and Fishers exact test calculation and comparison of the frequency of IgM and IA positivity between index and control mothers.

Study approval: The study was approved by the Ethical committee in Lund, Sweden (Decision number 2011/475). 


\section{RESULTS}

\subsection{Enterovirus IgM levels and frequencies}

Serum available from a total of 448 index and 891 control mothers were analyzed for Enterovirus IgM (EV-IgM) (Figure 1; Table 1). The frequency of EV-IgM was $20 \%$ in both index and control mothers ( $\mathrm{p}=0.92$, Table 2). While healthy mothers (group A) and healthy mothers with beta cell autoantibodies (Group B) did not differ in EV-IgM, it was found that Group C index (24\%) but not control (0\%) mothers with type 1 diabetes had EV-IgM $(\mathrm{p}=0.29)$. Mothers with gestational diabetes (Group D) did not differ in frequency (21\% compared to $26 \%$, $\mathrm{p}=01)$.

The seasonal variation of EV-IgM in groups A-E, divided bi-annually (Nov-Apr; $\mathrm{p}=0.522$ and May-Oct $\mathrm{p}=0.487$ respectively) as well as further divided quarterly (Nov-Jan; $\mathrm{p}=0.661$, Feb-Apr; 0.755, May-Jul; $\mathrm{p}=1$ and Aug-Oct: $\mathrm{p}=0.310$ (Supplementary Table 1) revealed no difference between index and control mothers.

\subsection{Levels of beta cell autoantibodies}

Beta cell autoantibody levels are illustrated in Supplementary Figure 1. The median levels of GADA were 8 (range 3- 1393) $\mathrm{U} / \mathrm{mL} \mathrm{U} / \mathrm{mL}$ in index $(\mathrm{n}=431)$ and $7(1-1082 \mathrm{U} / \mathrm{mL}$ in control $(\mathrm{n}=868)$ mothers, $(\mathrm{p}=0.014)$. GADA were detected in $21 / 431(4.9 \%)$ index compared to $16 / 868$ (1.9\%) controls mothers $(\mathrm{p}=0.002)$.

The median levels of IA-2A in index $(\mathrm{n}=431)$ were $3(1-1158 \mathrm{U} / \mathrm{mL}$,$) and 2(1-473) \mathrm{U} / \mathrm{mL}$ in control mothers $(n=868, p=0.006)$. IA-2A was detected in 13/431 (3.0\%) index compared to 8/868 $(0.9 \%)$ controls mothers $(\mathrm{p}=0.005)$. ZnT8A median levels in index $(\mathrm{n}=431)$ were $26(1-$ 1166) $\mathrm{U} / \mathrm{mL}$ () and 25 (5-1006) $\mathrm{U} / \mathrm{mL}$ in control mothers $(\mathrm{n}=867, \mathrm{p}<0.001)$ The ZnT8A frequencies at the $99.5^{\text {th }}$ percentile was $5 / 431(1.2 \%)$ in index and $4 / 867(0.5 \%)$ in control mothers $(\mathrm{p}=0.168)$.

\subsection{Beta cell autoantibody frequencies}

The numbers of GADA, IA-2A or ZnT8A antibodies in index and control mothers are illustrated in Supplementary Table 3. Index mothers in group B were either single $(n=6$,) or double $(n=1)$ positive compared to single $(n=15)$, double $(n=1$; ) or triple $(n=1)$ positive $(p=0.064664)$. In mothers reporting type 1 diabetes (Group C), index and control mothers were single $(\mathrm{n}=8,5$ GADA and 3 IA-2A) or double (n=7; 6 GADA and IA-2A as well as 1 GADA and ZNT8A) or triple $(n=3)$ positive compared to single $(n=5 ; 4$ GADA, 1 IA-2A) or triple $(n=1)$ positive $(\mathrm{p}=0.177$, Supplementary Figure 1). Adding group B and C together revealed that index had more beta cell autoantibodies alone or in combination compared to control mothers $(p=0.037)$. 
None of the mothers in group A (Healthy Mothers), group D (Mothers with Type 2 Diabetes) or E (Mothers with gestational diabetes) had any beta cell autoantibody (Supplementary Table 2). The seasonal variation of beta cell autoantibodies in groups A-E indicated an increase frequency during the winter months Nov-Apr among index compared to control mothers $(p=0.022$, Supplementary Table 3). The observed difference was possibly explained by the months of Feb$\operatorname{Apr}(\mathrm{p}=0.014)$.

\subsection{EV- IgM and beta cell autoantibody frequencies combined}

The frequency of IgM combined with beta cell autoimmunity is summarized in Table 3. Groups were divided into IgM and IA double negative (index $n=325$, controls $n=680$ ), IgM positive and IA negative (index $n=81$, controls $n=166$ ), IgM negative and IA positive (index $n=19$, controls $\mathrm{n}=19$ ), IgM positive and IA positive (index $\mathrm{n}=6$, controls $\mathrm{n}=4$ ) and analyzed for the total distribution $(\mathrm{p}=0.039)$. 


\section{Discussion}

The major findings in the present study of EV-IgM and beta cell autoantibodies during the first trimester in index mothers giving birth to children who after one year of age had developed beta cell autoantibodies or type 1 diabetes indicate that beta cell autoimmunity was increased in index compared to control mothers. In the beta cell autoantibody positive mothers, it cannot be excluded that EV-IgM was more common compared to the control mothers. It is therefore possible to speculate that EV-IgM and beta cell autoantibodies during the first trimester may be associated with an increased risk for the offspring to develop beta cell autoimmunity and type 1 diabetes. The combination of EV-IgM and beta cell autoimmunity suggest that these mothers may have experienced an EV infection that is somehow related to beta cell autoimmunity affecting the fetus that it is prone to develop beta cell autoimmunity postpartum. Recent data suggest that the appearance of two or more beta cell autoantibodies was associated with $70 \%$ risk for type 1 diabetes within 10 years (Ziegler et al., 2013).

In interpreting our data, there are two possibilities. First, EV-IgM may have induced beta cell autoantibodies during the first trimester. The problem with this interpretation is that beta cell autoantibodies are of the IgG type. Hence, these autoantibodies tend to be persistent over months and years. A concomitant seroconversion would therefore be unexpected. Second, the other possibility is therefore that the EV-IgM suggests a relatively recent infection in an asymptomatic beta cell autoantibody positive mother.

The frequency of Enteroviral IgM antibodies did not differ between diabetes and control mothers. This in conjunction with the rather high positivity rates (20 and 19.7\% respectively) suggests additional genetic and possibly environmental triggers. A weakness of our study is the lack of genetic information, preferably HLA-type of the mothers and their offspring. We observe a seasonal pattern regarding IA-2A autoantibody levels and the birth-month of child; high levels were seen for the first 7 months of the year. To our knowledge this has not been reported before; children born early during the year means samples were taken during the autumn months. A seasonal pattern for enterovirus infections and the closely related parechovirus having a peak during the summer and autumn has been reported(Fischer, Midgley, Dalgaard, \& Nielsen, 2014; Nielsen, Bottiger, Midgley, \& Nielsen, 2013). Additional studies are needed to record seasonal patterns with seroconversion of beta cell autoantibodies ${ }^{28}$.

Previous studies(Dahlquist et al., 1995; Lindehammer, Hansson, et al., 2011; Tauriainen et al., 2007; Viskari et al., 2012) have investigated and suggested a link between Enterovirus infections and the subsequent appearance of beta cell autoantibodies in the mother during pregnancy. It was 
not possible in the present study to confirm these earlier findings as samples from the third trimester or at delivery were not available. The information of the beta cell autoantibody and type 1 diabetes status in the offspring from this 7-year cohort of first trimester mothers were validated through several studies. First, in mothers who gave birth to children in 2000-2004, we used the follow-up data in the DiPiS study(H. E. Larsson et al., 2008; Lundgren et al., 2014; Lynch et al., 2008) for beta cell autoantibodies and the national registry (Hanas, Lindgren, \& Lindblad, 2007)for type 1 diabetes. Second, in mothers giving birth in 2004-2007 we used the follow-up data from the Swedish children enrolled in the TEDDY study(Krischer et al., 2015). In a previous Finnish study with the same objective as in the present study, an enterovirus infection was reported in $19.3 \%$ among their index mothers, a frequency similar to ours $(20.0 \%)$ (Viskari et al., 2012). It's noted that the numbers for the control-groups differ (Viskari et.al $12.0 \%$-present study $19.0 \%$ ). Whether a country-specific difference, the methodology of the studies or other factors explain the difference for the control-groups is not known.

The etiology behind type 1 diabetes is complex with several environmental triggers in combination with HLA-genes contribute to the development not of diabetes as such but rather the appearance of a first appearing beta cell autoantibody to be followed by a prolonged period of asymptomatic beta cell autoimmunity that precede the clinical onset. Based on our results, it's possible to speculate of an IgM enterovirus infection in a subgroup of the index mothers with beta cell autoantibodies during the first trimester may have increased the risk of the offspring to develop beta cell autoantibodies and type 1 diabetes. The TEDDY study reported recently that gestational respiratory infections showed a consistent protective influence on IAA among children with the G allele in CTLA4 (ref: Lynch et al. 2017). The authors concluded that the role of gestation respiratory infections may depend on offspring HLA and CTLA-4 alleles and supports a bidirectional trigger for IAA or GADA as a first appearing $\beta$-cell autoantibody in early life (Lynch et al. 2017). It can therefore not be excluded that some of our mothers have had an infection during pregnancy that markedly affected the risk of the offspring to develop a beta cell autoantibody before 7 years of age.

A difference in beta cell autoantibody positivity between index (later giving birth to a child who developed diabetes) and controls mothers were related especially to the Scandinavian wintermonths (October-March). This seasonal variation is in line with previous studies and of possible importance since Enteroviruses is also associated to this season(Lynch et al., 2008). Further investigations of the birth-month of the children suggested a seasonal variation to the summermonths (July, August, September). 
Of importance, the frequency of IgM positive individuals was $24 \%(5 / 21)$ in index mothers with Type 1 diabetes compared to $0 \%(0 / 9$, precluding statistical calculations) controls mothers. It's well known that the risk of a child to develop type 1 diabetes is increased with an affected parent(Dahlquist et al., 1995). This is most likely due to genetic interacting with environmental factors.

Increased levels of serum cytokines in early pregnancy might increase the risk of type 1 diabetes in the offspring. If cytokines are markers for infection, further studies are needed evaluate if it is Enteroviral or parechoviralinfection (Lindehammer, Fex, et al., 2011). Recent study from our research group indicates that the presence of cord blood IA-2A autoantibodies was associated with an increased risk for type 1 diabetes in the child(Lundgren et al., 2014) .

Our results did not support the suggested association between enterovirus infection and development of Type 1 diabetes. These mothers with autoantibodies, giving birth to children with diabetes have no association to Enterovirus IgM primary infection in similarity to previous studies.

It's of interest that mothers with type 1 diabetes could be associated with an increased beta cell autoantibody frequency but not increased Enterovirus IgM antibody frequency. This suggests further research of antibody measurements as a preferable diagnostic tool compared to Enterovirus IgM antibody measurements when screening for early risk diabetic biomarkers. Whether beta cell autoantibodies do pass the placenta from mother to child or whether the genetic HLA association is to explain the association between increased autoantibodies in mothers and development of diabetes in the child is currently not known.

\section{Conclusion}

The results of our study do not suggest that maternal enterovirus infection during first trimester of the pregnancy should be considered as a risk factor for beta cell autoimmunity and type 1diabetes in the offspring. However, based on our key observations; 1) a difference between index and control mothers in the distribution of combined IgM antibodies and beta cell autoantibody frequency; and 2) increased frequency of $\operatorname{IgM}$ positive individuals among Type 1 diabetes index mothers, it cannot be excluded that enteroviruses contribute to the disease etiology in a subgroup of patients.

\section{Acknowledgements}

Authors contribution: The first author Alexander Lind statistically analyzed the raw data and wrote manuscript. Dr. Kristian F. Lynch takes responsibility for the accuracy of the data 
analysis. Dr. Markus Lundgren contributed with the DiPiS study data and reviewed the manuscript. Professor Åke Lernmark and Dr. Annika Lundstig corresponding author are the guarantors of this work and had full access to all data and take responsibility for the integrity of this study. Dr. Peter Almgren and Anita Ramelius performed identification and matching of the local database registries. Professor Heikki Hyöty and Leena Puustinen were responsible for the Enterovirus IgM capture enzyme immunoassay analysis. Dr. Annika Lundstig performed all the serology laboratory analysis. All authors contributed to discussion and revision of the manuscript.

We thank Ahmed Delli and from the Southern Sweden Microbiological Biobank (SSM-

Biobank), Maria Hortlund and Berit Nilsson for assistance and laboratory technician Aaro Piirainen from University of Tampere for technical assistance with the ELISA tests.We express our gratitude to the children and parents participating in the DiPiS and TEDDY study. 


\section{References}

Baekkeskov, S., Landin, M., Kristensen, J. K., Srikanta, S., Bruining, G. J., Mandrup-Poulsen, T., . . et al. (1987). Antibodies to a 64,000 Mr human islet cell antigen precede the clinical onset of insulin-dependent diabetes. J Clin Invest, 79(3), 926-934. doi: 10.1172/JCI112903

Barker, J. M., Goehrig, S. H., Barriga, K., Hoffman, M., Slover, R., Eisenbarth, G. S., . . study, Daisy. (2004). Clinical characteristics of children diagnosed with type 1 diabetes through intensive screening and followup. Diabetes Care, 27(6), 1399-1404.

Beyerlein, A., Wehweck, F., Ziegler, A. G., \& Pflueger, M. (2013). Respiratory infections in early life and the development of islet autoimmunity in children at increased type 1 diabetes risk: evidence from the BABYDIET study. JAMA Pediatr, 167(9), 800-807. doi: 10.1001/jamapediatrics.2013.158

Cabrera-Rode, E., Sarmiento, L., Tiberti, C., Molina, G., Barrios, J., Hernandez, D., . . Di Mario, U. (2003). Type 1 diabetes islet associated antibodies in subjects infected by echovirus 16. Diabetologia, 46(10), 1348-1353. doi: 10.1007/s00125-003-1179-4

Dahlquist, G. G., Ivarsson, S., Lindberg, B., \& Forsgren, M. (1995). Maternal enteroviral infection during pregnancy as a risk factor for childhood IDDM. A population-based case-control study. Diabetes, 44(4), 408-413.

Eisenbarth, G. S. (2004). Prediction of type 1 diabetes: the natural history of the prediabetic period. Adv Exp Med Biol, 552, 268-290.

Fischer, T. K., Midgley, S., Dalgaard, C., \& Nielsen, A. Y. (2014). Human parechovirus infection, Denmark. Emerg Infect Dis, 20(1), 83-87. doi: 10.3201/eid2001.130569

Group, Teddy Study. (2007). The Environmental Determinants of Diabetes in the Young (TEDDY) study: study design. Pediatr Diabetes, 8(5), 286-298. doi: 10.1111/j.1399-5448.2007.00269.x

Grubin, C. E., Daniels, T., Toivola, B., Landin-Olsson, M., Hagopian, W. A., Li, L., . . Lernmark, A. (1994). A novel radioligand binding assay to determine diagnostic accuracy of isoform-specific glutamic acid decarboxylase antibodies in childhood IDDM. Diabetologia, 37(4), 344-350.

Hanas, R., Lindgren, F., \& Lindblad, B. (2007). Diabetic ketoacidosis and cerebral oedema in Sweden--a 2-year paediatric population study. Diabet Med, 24(10), 1080-1085. doi: 10.1111/j.1464-5491.2007.02200.x

Hober, D., \& Sane, F. (2010). Enteroviral pathogenesis of type 1 diabetes. Discov Med, 10(51), 151-160.

Hober, D., \& Sauter, P. (2010). Pathogenesis of type 1 diabetes mellitus: interplay between enterovirus and host. Nat Rev Endocrinol, 6(5), 279-289. doi: 10.1038/nrendo.2010.27

Kjelleras, J., Vaziri-Sani, F., \& Agardh, D. (2011). Improved efficacy by using the pTnT-rhtTG plasmid for the detection of celiac disease specific tissue transglutaminase autoantibodies in radioligand binding assays. Scand J Clin Lab Invest, 71(8), 701-704. doi: 10.3109/00365513.2011.619564

Krischer, J. P., Lynch, K. F., Schatz, D. A., Ilonen, J., Lernmark, A., Hagopian, W. A., . . Group, Teddy Study. (2015). The 6 year incidence of diabetes-associated autoantibodies in genetically at-risk children: the TEDDY study. Diabetologia, 58(5), 980-987. doi: 10.1007/s00125-015-3514-y

Larsson, H. E., Hansson, G., Carlsson, A., Cederwall, E., Jonsson, B., Jonsson, B., . . DiPi, S. Study Group. (2008). Children developing type 1 diabetes before 6 years of age have increased linear growth independent of HLA genotypes. Diabetologia, 51(9), 1623-1630. doi: 10.1007/s00125-008-1074-0

Larsson, K., Elding-Larsson, H., Cederwall, E., Kockum, K., Neiderud, J., Sjoblad, S., . . Lernmark, A. (2004). Genetic and perinatal factors as risk for childhood type 1 diabetes. Diabetes Metab Res Rev, 20(6), 429437. doi: 10.1002/dmrr.506

Lernmark, B., Lynch, K., \& Lernmark, A. (2006). Cord blood islet autoantibodies are related to stress in the mother during pregnancy. Ann N Y Acad Sci, 1079, 345-349. doi: 10.1196/annals.1375.053

Lindehammer, S. R., Fex, M., Maziarz, M., Hanson, I., Marsal, K., Lernmark, A., \& Diabetes Prediction in Skane Study, Group. (2011). Early-pregnancy cytokines in mothers to children developing multiple, persistent islet autoantibodies, type 1 diabetes, or both before 7 years of age. Am J Reprod Immunol, 66(6), 495-503. doi: 10.1111/j.1600-0897.2011.01057.x

Lindehammer, S. R., Hansson, I., Midberg, B., Ivarsson, S. A., Lynch, K. F., Dillner, J., . . Diabetes Prediction in Skane Study, Group. (2011). Seroconversion to islet autoantibodies between early pregnancy and delivery in non-diabetic mothers. J Reprod Immunol, 88(1), 72-79. doi: 10.1016/j.jri.2010.10.002

Lundgren, M., Sahlin, A., Svensson, C., Carlsson, A., Cedervall, E., Jonsson, B., . . DiPi, S. study group. (2014). Reduced morbidity at diagnosis and improved glycemic control in children previously enrolled in DiPiS follow-up. Pediatr Diabetes, 15(7), 494-501. doi: 10.1111/pedi.12151

Lynch, K. F., Lernmark, B., Merlo, J., Cilio, C. M., Ivarsson, S. A., Lernmark, A., \& Diabetes Prediction in Skane Study, Group. (2008). Cord blood islet autoantibodies and seasonal association with the type 1 diabetes high-risk genotype. J Perinatol, 28(3), 211-217. doi: 10.1038/sj.jp.7211912

Nielsen, A. C., Bottiger, B., Midgley, S. E., \& Nielsen, L. P. (2013). A novel enterovirus and parechovirus multiplex one-step real-time PCR-validation and clinical experience. J Virol Methods, 193(2), 359-363. doi: 10.1016/j.jviromet.2013.06.038

Resic Lindehammer, S., Honkanen, H., Nix, W. A., Oikarinen, M., Lynch, K. F., Jonsson, I., . . Lernmark, A. (2012). Seroconversion to islet autoantibodies after enterovirus infection in early pregnancy. Viral Immunol, 25(4), 254-261. doi: 10.1089/vim.2012.0022 
Ryding, J., French, K. M., Naucler, P., Barnabas, R. V., Garnett, G. P., \& Dillner, J. (2008). Seroepidemiology as basis for design of a human papillomavirus vaccination program. Vaccine, 26(41), 5263-5268. doi: 10.1016/j.vaccine.2008.07.041

Sadeharju, K., Lonnrot, M., Kimpimaki, T., Savola, K., Erkkila, S., Kalliokoski, T., . . Hyoty, H. (2001). Enterovirus antibody levels during the first two years of life in prediabetic autoantibody-positive children. Diabetologia, 44(7), 818-823. doi: 10.1007/s001250100560

Salminen, K., Sadeharju, K., Lonnrot, M., Vahasalo, P., Kupila, A., Korhonen, S., . . Hyoty, H. (2003). Enterovirus infections are associated with the induction of beta-cell autoimmunity in a prospective birth cohort study. $J$ Med Virol, 69(1), 91-98. doi: 10.1002/jmv.10260

Sarmiento, L., Cubas-Duenas, I., \& Cabrera-Rode, E. (2013). Evidence of association between type 1 diabetes and exposure to enterovirus in Cuban children and adolescents. MEDICC Rev, 15(1), 29-32.

Tauriainen, S., Martiskainen, M., Oikarinen, S., Lonnrot, M., Viskari, H., Ilonen, J., . . Hyoty, H. (2007). Human parechovirus 1 infections in young children--no association with type 1 diabetes. J Med Virol, 79(4), 457462. doi: 10.1002/jmv.20831

Torn, C., Mueller, P. W., Schlosser, M., Bonifacio, E., Bingley, P. J., \& Participating, Laboratories. (2008). Diabetes Antibody Standardization Program: evaluation of assays for autoantibodies to glutamic acid decarboxylase and islet antigen-2. Diabetologia, 51(5), 846-852. doi: 10.1007/s00125-008-0967-2

Viskari, H., Knip, M., Tauriainen, S., Huhtala, H., Veijola, R., Ilonen, J., . . Hyoty, H. (2012). Maternal enterovirus infection as a risk factor for type 1 diabetes in the exposed offspring. Diabetes Care, 35(6), 1328-1332. doi: $10.2337 / \mathrm{dc} 11-2389$

Ziegler, A. G., Rewers, M., Simell, O., Simell, T., Lempainen, J., Steck, A., . . Eisenbarth, G. S. (2013). Seroconversion to multiple islet autoantibodies and risk of progression to diabetes in children. JAMA, 309(23), 2473-2479. doi: 10.1001/jama.2013.6285 
Table 1. Study participants and their demographic characteristics

\begin{tabular}{|c|c|c|}
\hline & Index mothers & Control mothers \\
\hline Total number of subjects & 448 & 891 \\
\hline $\begin{array}{l}\text { A. Healthy mothers } \\
\text { Age (median and range) }\end{array}$ & $\begin{array}{c}401 \\
(30,19-43)\end{array}$ & $\begin{array}{c}812 \\
(30,18-43)\end{array}$ \\
\hline $\begin{array}{l}\text { B.Healthy Mothers with } \\
\text { Beta cell autoantibodies } \\
\text { Age (median and range) }\end{array}$ & $\begin{array}{c}7 \\
(33,26-35)\end{array}$ & $\begin{array}{c}17 \\
(32,24-39)\end{array}$ \\
\hline $\begin{array}{l}\text { C.Mothers with Type } 1 \text { diabetes } \\
\text { Age (median and range) }\end{array}$ & $\begin{array}{c}21 \\
(31,23-37)\end{array}$ & $\begin{array}{c}9 \\
(32,20-37)\end{array}$ \\
\hline $\begin{array}{l}\text { D.Mothers with } \\
\text { Type } 2 \text { diabetes } \\
\text { Age (median and range) }\end{array}$ & --- & $\begin{array}{c}2 \\
(32.5,32-33)\end{array}$ \\
\hline $\begin{array}{l}\text { E. Mothers with gestational } \\
\text { diabetes (GDM) } \\
\text { Age (median and range) }\end{array}$ & $\begin{array}{c}19 \\
(32,26-39)\end{array}$ & $\begin{array}{c}51 \\
(32,22-42)\end{array}$ \\
\hline
\end{tabular}

Table 2. Frequency of EV-IgM in index and control mothers.

\begin{tabular}{|l|c|c|c|}
\hline & Index mothers & Control mothers & p-value \\
\hline Total number of subjects & $89 / 448(20 \%)$ & $175 / 891(20 \%)$ & 0.922 \\
\hline A. Healthy mothers & $79 / 401(20 \%)$ & $157 / 812(19 \%)$ & 0.88 \\
\hline $\begin{array}{l}\text { B. Healthy mothers with } \\
\text { beta cell Autoantibodies }\end{array}$ & $1 / 7(14 \%)$ & $4 / 17(24 \%)$ & 1 \\
\hline C. Mothers with Type 1 diabetes & $5 / 21(24 \%)$ & $0 / 9(0 \%)$ & 0.29 \\
\hline D. Mothers with Type 2 diabetes & --- & $1 / 2(50 \%)$ & -- \\
\hline $\begin{array}{l}\text { E. Mothers with gestational } \\
\text { diabetes (GDM) }\end{array}$ & $4 / 19(21 \%)$ & $13 / 51(26 \%)$ & 1 \\
\hline
\end{tabular}

Fischer exact test was used for p-value. 
Table 3. EV- IgM and beta cell autoantibodies in index and control mothers.

\begin{tabular}{|c|c|c|c|c|}
\hline EV-IgM & IA (all 3) & Index (\%) & Controls (\%) & \\
\hline- & - & $325(75)$ & $680(78)$ & \\
\hline+ & - & $81(19)$ & $166(19)$ & \\
\hline- & + & $19(4)$ & $19(2)$ & \\
\hline+ & + & $6(2)$ & $4(1)$ & \\
\hline & & $431(100)$ & $869(100)$ & $1300(p=0.039)$ \\
\hline
\end{tabular}

Fischer exact test was used for $\mathrm{p}$-value. 


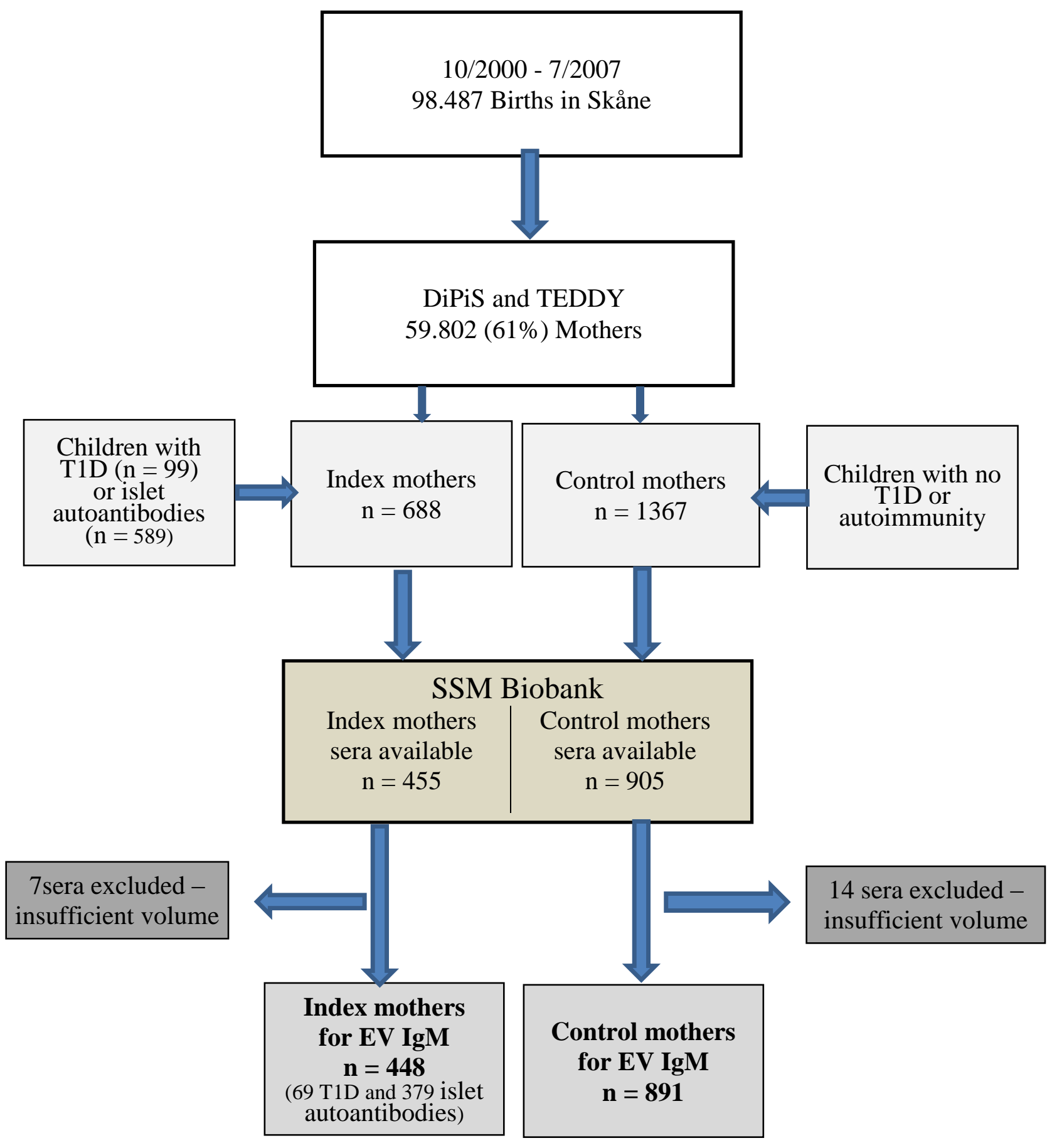


Authors contribution: The first author Alexander Lind statistically analyzed the raw data and wrote manuscript. Dr. Kristian F. Lynch takes responsibility for the accuracy of the data analysis. Dr. Markus Lundgren contributed with the DiPiS study data and reviewed the manuscript. Professor Åke Lernmark and Dr. Annika Lundstig corresponding author are the guarantors of this work and had full access to all data and take responsibility for the integrity of this study. Dr. Peter Almgren and Anita Ramelius performed identification and matching of the local database registries. Professor Heikki Hyöty and Leena Puustinen were responsible for the Enterovirus IgM capture enzyme immunoassay analysis. Dr. Annika Lundstig performed all the serology laboratory analysis. All authors contributed to discussion and revision of the manuscript There are no financial or other conflicts of interest for any of the authors.

Corresponding author:

Annika Lundstig, Ph.D.

Lund University Diabetes Centre

Department of Clinical Sciences

Malmö University Hospital, CRC

Jan Waldenströms gata 35

20502 Malmö, Sweden

E-mail: annika.lundstig@med.lu.se

Phone:+46 709-532199, 46 40-391019 